\title{
MULTI SCALE DISASTER RISK REDUCTION SYSTEMS, SPACE AND COMMUNITY BASED EXPERIENCES OVER HKH REGION
}

\author{
Deo Raj Gurung a, *, Mandira Shrestha ${ }^{\text {a }}$, Neera Shrestha ${ }^{a}$, Bijan Debnath ${ }^{\text {a }}$, Govinda Joshi ${ }^{\text {a }}$, Rajan Bajracharya ${ }^{\text {a }}$, Hari Krishna \\ Dhonju ${ }^{a}$, Sudip Pradhan ${ }^{\text {a }}$ \\ a International Centre for Integrated Mountain Development, Kathmandu, Nepal, Tel +977-1-5003222 Fax +977-1- \\ 5003277 (deoraj.gurung, mandira.shrestha, neera.shrestha, bijan.debnath, govinda.joshi, rajan.bajracharya, \\ harikrishna.dhonju, sudip.pradhan)@icimod.org
}

KEY WORDS: Disaster, Hindu Kush Himalaya, Geospatial, Disaster risk reduction

\begin{abstract}
:
An increasing trend in the recurrence of natural disasters and associated impacts due to Floods, Glacier Lake out bursts, landslides and forest fire is reported over Hindu Kush Himalyan (HKH) region. Climate change and anthropogenic coupled factors are identified as primary factors for such increased vulnerability. The large degree of poverty, lack of infrastructure, poor accessibility and uncertainties involved in understanding high altitude land surface and climate dynamics poses serious challenges in reducing disaster vulnerability and mitigating disaster impacts. In this context effective development of Disaster Risk Reduction (DRR) protocols and mechanisms have been realized as an urgent need. The paper presents the adoption and experiences of multi scale DRR systems across different Himalayan member countries ranging from community based indigenous early warning to space based emergency response and decision support systems.
\end{abstract}

The Establishment of a Regional Flood Information System (HKH-HYCOS) over Ganges-Brahmaputra-Meghna (GBM) and Indus river basins promoted the timely exchange of flood data and information for the reduction of flood vulnerability within and among the participating countries. Satellite based forest fire alert systems evoked significant response among diverse stakeholders to optimize fire incidence and control. Satellite rainfall estimation products, satellite altimetry based flood early warning systems, flood inundation modelling and products, model derived hydrology flow products from different global data-sharing networks constitutes diverse information to support multi scale DRR systems. Community-based Flood Early Warning System (FEWS) enabled by wireless technology established over the Singara and Jiadhal rivers in Assam also stands as one of the promising examples of minimizing flood risk. Disaster database and information system and decision support tools in Nepal serves as potential tool to support diverse stakeholders.

\section{INTRODUCTION}

The increasing number of disaster incidents and associated cost over the years attributed to rise in extreme events and unsustainable development practices (Coumou and Rahmstorf 2012; Schiermeier 2012), resonates a story line very true in the context of Hindu Kush Himalayan (HKH) region. The HKH region encompassing high mountain landscape of countries across Hindu Kush, Karakoram and Himalaya ranges, viz. Afghanistan, Bangladesh, Bhutan, China, India, Myanmar, Nepal and Pakistan, measuring over 4.1 million sq.km in area (Bajracharya and Shrestha 2011), is prone to natural disaster of myriad types. The region characterized by active geo-tectonic setting, sensitive to climate extremes, fragile ecology, and wide spread poverty are confronted with challenges of many kinds, including adverse impact of natural disaster. The role of geospatial tool which includes both remote sensing (RS) and geographical information system (GIS) as an enabling framework for timely generation of data, quick analysis, management and dissemination has long been recognized (Ali Tahir 2007; Abdalla and Li 2010; Goodchild 2006). UN facilitated global discourse in Rio de Janeiro, Brazil on sustainable "recognize the importance of space-technologybased data, in situ monitoring and reliable geospatial information for sustainable development policymaking, programming and project operations"(UN 2012). Importance will only increase with time as data becomes available and cost of software and hardware comes down (Zerger and Smith 2003).
The International Centre for Integrated Mountain Development (ICIMOD), an inter-governmental agency promoting sustainable development agenda in the HKH region since 1983, is strong advocate of geo-spatial technology in development agenda, and has over the years leveraged technological benefits to safe guard vulnerable communities by enhancing community resilience to disaster through timely access to information and promoting disaster sensitive planning. It encompasses framing a multi-level risk mapping system, satellite based mapping support, piloting innovative technological solution, and implementing community based DRR pilot interventions. Activities undertaken by ICIMOD as highlighted are of different geographical scales - regional, national, and local level. The need for assimilation of different levels of information at multi-level of policy support is addressed with the wide ranging DRR activities at ICIMOD.

\section{MATERIAL AND METHOD}

\subsection{Study Area}

There is a need for regional framework for collaboration due to trans-boundary nature of disaster types, and multi-level approach due to differentiated informational needs for policy support at different level of policy making process, while addressing disaster. ICIMOD pursues transect and basin approach as framework for program engagement to facilitate collaborative research. ICIMOD being an inter-governmental organization working across 8 member states, engages in both regional (more than one country) and national scale. The

\footnotetext{
* Corresponding author. This is useful to know for communication with the appropriate person in cases with more than one author.
} 
Regional Flood Information System in the Hindu Kush Himalayan Region (HKH-HYCOS), a program working to establish hydro-met stations across participating countries with an aim to minimize loss of lives and livelihoods in the GangesBrahmaputra-Meghna and Indus river basins (Figure 1). Inventory of glacial lakes and glaciers, and identification of potentially dangerous glacial lakes is another case of regional engagement, covering Afghanistan in the west to Arunachal Pradesh in the east. Koshi Basin Program (KBP), a basin wide approach engages China, Nepal and India (Figure 1) to enhance the regionally coordinated management of the Koshi basin. Basin wide landslide hazard assessment is being done for Koshi basin. ICIMOD realizing the need to bring in affordable technological innovations to boost up disaster risk management has piloted cutting edge technology in case of flood and landslide. A community based flood early warning system using low cost wireless communication network has been piloted in Dhemaji district of Assam, while test of locally developed unmanned aerial survey system (UASS) is being pursued in Jure landslide of Sindupalchowk district in Nepal.

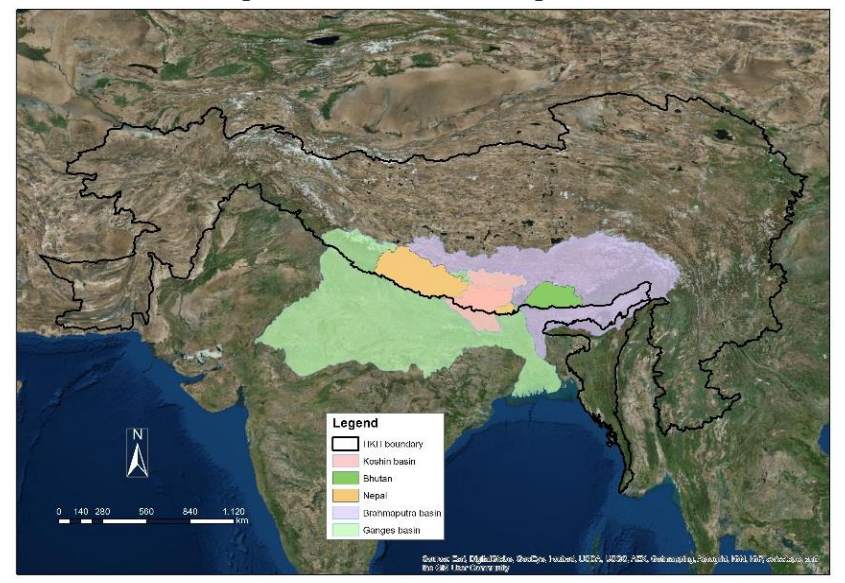

Figure 1. Location map showing activity sites.

\section{MULTI-LEVEL ENGAGEMENT FOR FLOOD RISK MANAGEMENT}

\subsection{Regional flood information system (RFIS) and flood outlooks}

Occurrence of floods of large intensity and magnitude are increasing in the $\mathrm{HKH}$ region resulting in impediment to socioeconomic development of the region. The 2010 floods of Pakistan and Uttarakhand flood of 2013 are recent cases of catastrophic events with millions of dollar in economic loss. All these floods call for the need for people oriented early warning systems (EWS) which reach out to the people in a timely manner for actionable response.

To support flood disaster prevention and management at regional level, ICIMOD, the World Meteorological Centre (WMO) and the partner countries developed the HKH-HYCOS project with the financial support of the Government of Finland to enhance regional cooperation and technical capacities for hydro-meteorological data collection and sharing. The overall objective is to minimise loss of human lives and property damage through timely exchange of flood data and information between and among partner countries. In consultation with the partners the location of the hydro-meteorological stations were identified and in total 38 hydromet stations were upgraded in four countries Bangladesh, Bhutan, Nepal and Pakistan. State of the art water and weather monitoring sensors were installed conforming to WMO standards. The data is being transmitted through direct telemetry (GSM/CDMA with satellite iridium as a backup) to the national hydro-meteorological services of the four countries and to the regional server at ICIMOD.

The RFIS comprises of effective data and information transmission and reception capabilities, adequate national and regional databases and data management systems, and the requisite technical expertise. The regional and national flood information systems are developed as web-based systems (Figure 2). In order to ensure sustainability the field technicians have been trained in operation and maintenance of the hydrometeorological stations.

To demonstrate the utility of flood data and information a regional flood outlook has been piloted in the Ganges and Brahmaputra basins in the monsoon of 2014. The hydrologic and hydrodynamic models were set up using the DHI Mike11 software. The SRTM 90 m DEM, globally available data such as the GFS forecasts, TRMM 3B42 NRT rainfall, as well as real-time meteorological data were used to develop the model. The model was then calibrated and validated with insitu data. The model produced three day flood outlooks i.e. $24 \mathrm{hr}, 48 \mathrm{hr}$ and $72 \mathrm{hr}$, for 21 nodes in the Ganges and Brahmaputra basins. A flood situation was correctly estimated for the period 14-16 August 2014 in various river basins including Koshi at Chatara, Karnali at Chisapani and Narayani at Devghat in Nepal when intense rainfall occurred across the Himalayas.

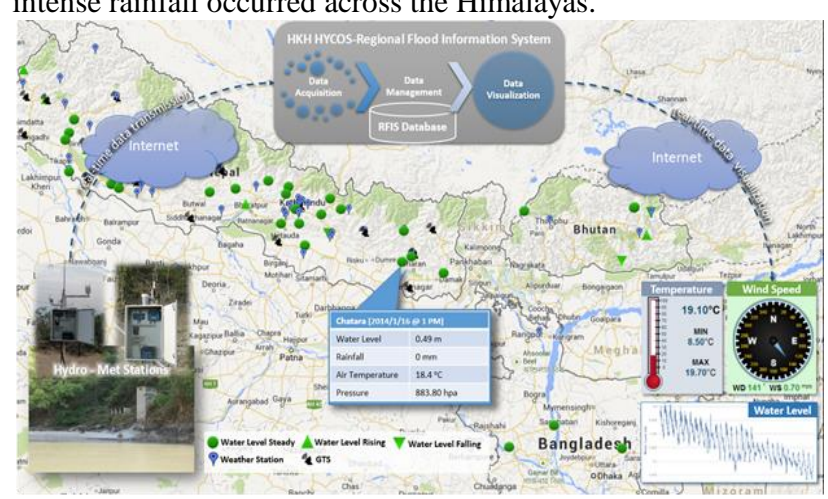

Figure 2. Screenshot of RIFS web interface with schematic showing data flow.

\subsection{Community based flood early warning system}

Communities residing in high hazard zones are always at the receiving end of disaster and often vulnerable due to low social standing with limited access to resources needed to cope with the disaster. ICIMOD piloted community based flood EWS (CB-EWS) in Jiadhal River basin, Dhemaji, Assam (India) jointly with Aaranyak, NGO, India. The river Jiadhal, a north bank tributary of river Brahmaputra originates in the lower Himalayan ranges in West Siang District of Arunachal Pradesh at an altitude of 1247 meter above mean seal level (Das 2011). In Assam it flows through the Dhemaji district frequently migrating and changing its course unpredictably almost in every flood season (Brahmaputra Board, 2000), thus causing damage to lives and livelihoods of the local community.

The CB-EWS constitutes combination of low cost warning mechanism and community response mechanism. The alert module consisting of a siren connected to control unit is placed in house of host family who has been provided with home light unit that works on LED along with a mobile phone and charger as an incentive for taking care. Fore warning generated by assembly of instrumentations referred as AL6M (manufactured by a Nepal based company, 'Sustainable Eco Engineering Pvt. Ltd.) based on the flood gauge placed in upper reaches of the 
river is communicated by host family to other villagers. There are altogether 6 levels of warning based on calibration done through wider consultation with villagers. In 2010 the system successfully alerted villages in Kesakathani village and Dhiri village in Dhemaji District saving property worth USD 3,500 (Das 2011).

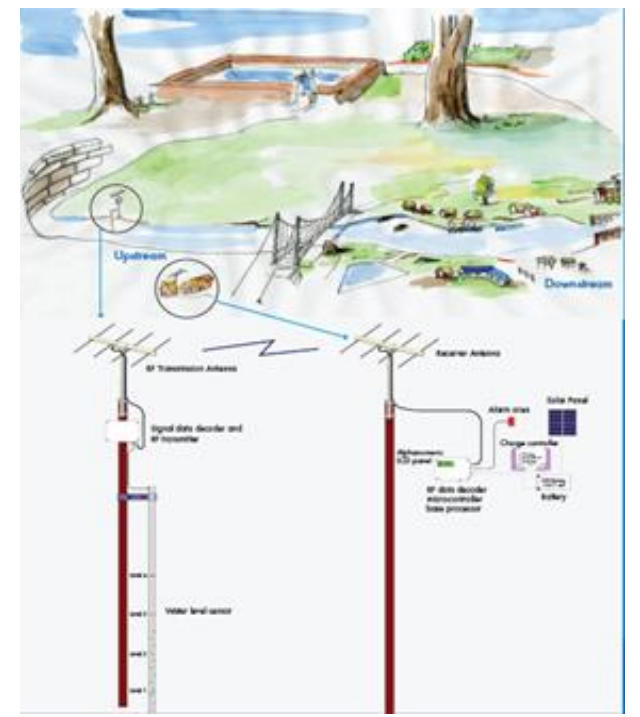

Figure 3. Schematic design of CB-FEWS.

Capacity building of villagers on response strategy and awareness building was pursued along the instrumentation so that villagers are able to manage the system and situation in case of an event.

\section{EFFECTIVE PREPAREDNESS THROUGH ACCESS TO RIGHT INFORMATION}

\subsection{Multi-level risk assessment framework}

One of the priority under Hyogo Framework for Action 20052015 is "Strengthen disaster preparedness for effective response at all levels" (ISDR 2005), which underscores the need for multi-level framework for risk assessment. Mainstreaming of DRR must happen at all levels of development planning and policy making process. The underlying needs for differentiated information and policy support mechanism at multi-levels of policy making process, warrants appropriate framework in place. ICIMOD under SERVIR Himalaya Initiative (https://www.servirglobal.net/Himalaya.aspx), with funding support from NASA and USAID, as a proof of concept of multilevel risk assessment framework developed a system to assess risk at national, sub-national and local levels, taking Nepal as pilot case.

The system is based on both qualitative (national and subnational level assessment) and quantitative (local level) methods. Assessment at national level (across districts) and subnational (across Village Development Committees) are based on historical disaster events and socio-economic data. The Village Development Committees (VDC) are sub-district level administrative units in Nepal. Hazard is simply an event and is assessed using frequency rating based on historical disaster event database collated and maintained by Ministry of Home Affairs (MoHA), made available for the years from 2000 to 2014. The system generates choropleth map of event (hazard) frequency and measure of impact on people (people killed) and economy (estimated economic loss), decisive for effective planning and appropriate budget provisioning.

Vulnerability is the starting point for risk reduction intervention and is a measure of the propensity of an exposed elements to incur consequences of a hazard. Thus enhanced knowledge on distribution of vulnerable groups is vital information for effective lay out of preparedness and response strategies (Birkmann 2007) to boost disaster resilience of vulnerable groups. According to the UNDP Bureau for Crisis Prevention and Recovery (UNDP 2004:11), human vulnerability is "a condition or process resulting from physical, social, economic and environmental factors, which determines the likelihood and scale of damage from the impact of a given hazard". Indicators used for vulnerability analysis of Ramechhap district is summarized in Table 1, and access to the product is through online web interface (Figure 4).

\begin{tabular}{|c|c|c|}
\hline No & Indicators & Description \\
\hline 1 & Population density & Density of population \\
\hline 2 & Dependency ratio & $\begin{array}{l}\text { Ration between number of } \\
\text { children and older persons to } \\
\text { working age population. }\end{array}$ \\
\hline 3 & Poverty & $\begin{array}{l}\text { Number of people under } \\
\text { poverty line }\end{array}$ \\
\hline 4 & $\begin{array}{l}\text { Access to health } \\
\text { facility }\end{array}$ & $\begin{array}{l}\text { Type and number of health } \\
\text { facility in the district }\end{array}$ \\
\hline 5 & Road density & $\begin{array}{l}\text { Density of road in the } \\
\text { district. }\end{array}$ \\
\hline 6 & $\begin{array}{l}\text { Access } \\
\text { information }\end{array}$ & $\begin{array}{l}\text { Numbers of people with } \\
\text { access to communication } \\
\text { gadgets. }\end{array}$ \\
\hline 7 & $\begin{array}{l}\text { Land degradation } \\
\text { rate }\end{array}$ & $\begin{array}{l}\text { Net forest area change in the } \\
\text { district. }\end{array}$ \\
\hline
\end{tabular}

The method to calculate vulnerability is outlined by UNESCOIHE (http://unescoihefvi.free.fr/flood_vulnerability_factors.php) as presented in Equation 1.

Vulnerability $=$ Exposure + Susceptibility - Resilience $\ldots .$. Eq. 1

The informational need at the grassroots is more of operational kind than strategic, and requires detailed distribution of hazard and risk at much finer unit/resolution. For the local level hazard and risk mapping, modelled output implemented at Lal Bakaiya watershed in Nepal (ADAPT-Nepal 2011) has been used to map hazard and risk mapping. The 1D hydrodynamic model (HEC Series) has been used for inundation mapping and hazard zonation is done by adopting hazard scheme based on inundation depth, a straight forward approach. Risk assessment in this case is done based on population density (distribution of population) adopted for quick and easy approach as compared to field intensive analysis. Population density is estimated using dasymetric method, an areal interpolation method (Chen et al. 2004; Mennis 2003) implemented using administrative unit disaggregated population data and landcover data derived from Landsat images. The philosophy behind risk mapping is higher risk factor for pixels with high population density and high flood depth, and vice versa. 


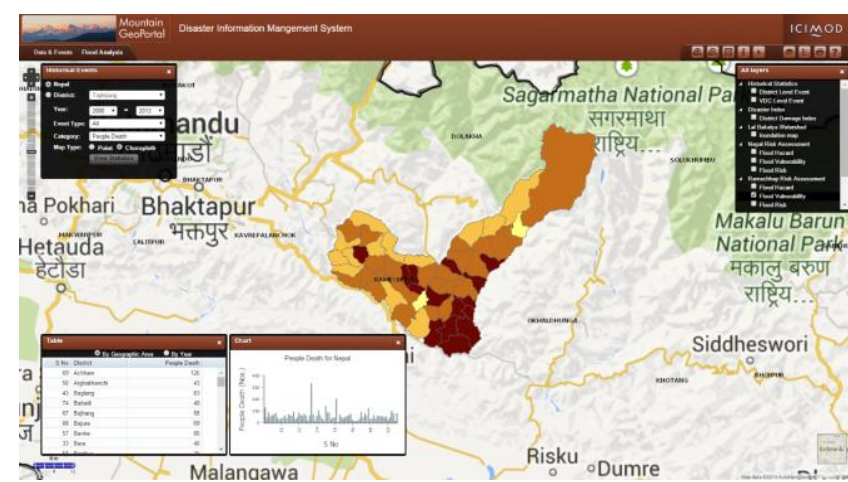

Figure 4. Vulnerability profile of Ramechaap district, Nepal.

\subsection{GLOF risk assessment framework}

High mountains are sensitive to climate change (Beniston 2003; Shrestha et al. 2010), and its' impact is perceived in many different ways including rapid decay of glaciers (Kaab et al. 2007; Bajracharya et al. 2014; Karma et al. 2003). Enhanced rate of glacier melting and impoundment of melt water behind moraine results in formation of glacial lake which in recent past is seen to increase in size and number across the $\mathrm{HKH}$ region (Komori 2008; Bajracharya and Mool 2009; Bajracharya et al. 2007). The chance of failure of moraine dam due to internal and external triggering mechanism as seen in many glacial lake outburst floods (GLOF)in the past presents serious threats for

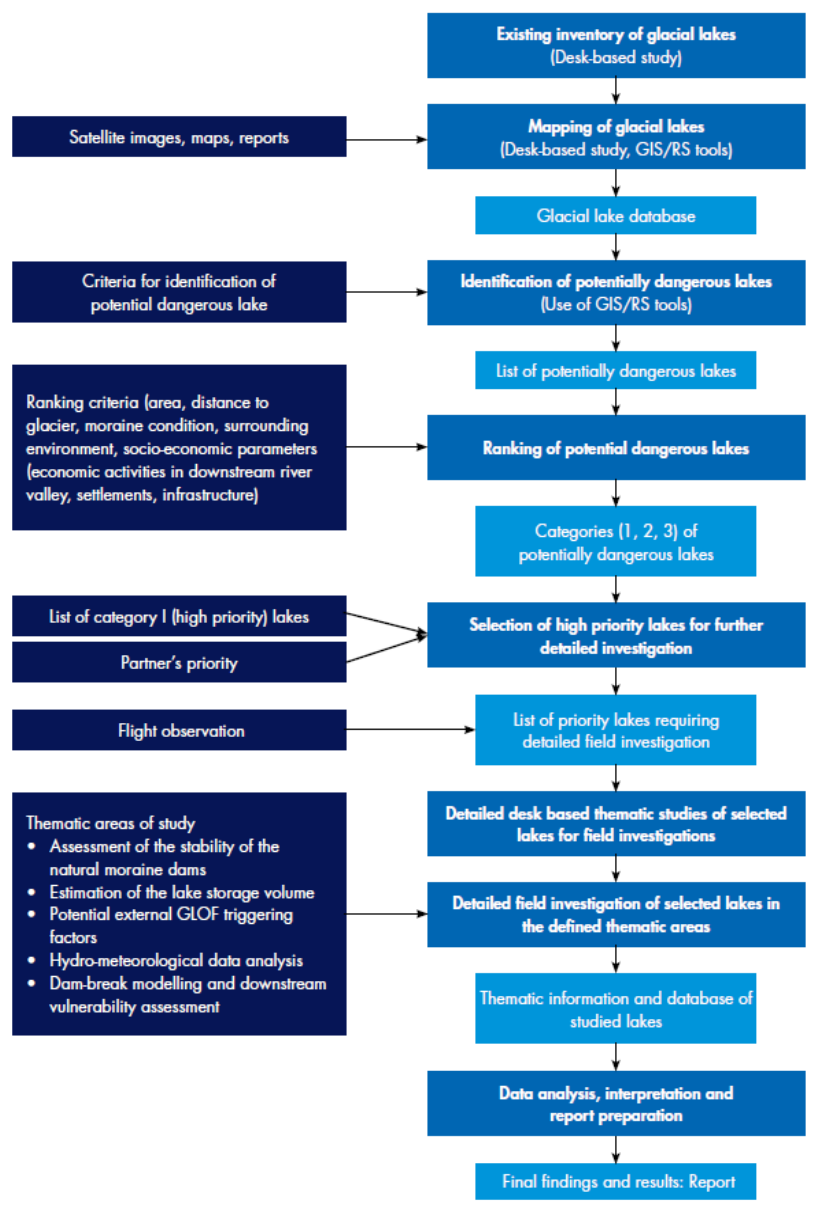

Figure 5. Workflow of step by step GLOF risk assessment methodology. (Source: ICIMOD 2011) downstream communities (Ives et al. 2010; Bolch et al. 2008; Quincey et al. 2007; Richardson and Reynolds 2000; Komori et al. 2012). Tracking changes in glaciers and glacial lakes over time using multi-temporal satellite data provides a tool to monitor both potential threat and water resource, so appropriate and timely actions can be devised.

ICIMOD pioneered glacier and glacial lake inventory work based on remote sensing approach in latter half of 1990s' and has so far developed two generation of inventories. The first inventory released in 2001 (Mool et al. 2001a; Mool et al. 2001b) are based on satellite data (TM, SPOT, IRS, JERS), aerial photographs, and topo maps dated between 1960s and 2000. Second generation of glacier inventory was released in 2013 and was based on TM and ETM+ of base year 2005 ( \pm 3 years). The first inventory mapped about 15,000 glacier and 9000 glacial lakes out of which over 200 were identified as potentially dangerous glacial lakes.

The HKH region has so far witnessed 35 GLOFs in the past (Shrestha et al. 2010) and threat looms large with rapid deglaciation attributed to climate change. The livelihood opportunities offered by perennial rivers originating from glacier and glacial lakes saw many urban facilities and infrastructures concentrated in hazard prone downstream stretches. Reflecting on some incidents of past and incurred economic losses from GLOF events donors, project financiers and/or insurance companies require a comprehensive risk assessment for new development projects.

The limited study done so far on downstream risk assessment from GLOF in HKH region is confined to hazard assessment while risk element is completely left out (Shrestha et al. 2010). To this end a framework for comprehensive GLOF risk assessment (Figure 5) encompassing a hazard assessment of the lake as well as a physical and social vulnerability assessment of the downstream impact areas has been implemented in the case of 4 glacial lakes: Imja, Thulagi, Tsho Rolpa, and Lumi Chimi (Shrestha et al. 2010; ICIMOD 2011). The framework includes both remote sensing based glacial lake inventory and prioritization of critical glacial lakes, and analysis of field based information of exposure elements (population and infrastructure).

\subsection{Landslide susceptibility mapping initiative}

Slope failure is typical problem of mountain landscape and landslide constitute most common type of slope failure in the HKH region (Kuenza et al. 2004; Pareta et al. 2012; Bhattarai and Pradhan 2013; Kayastha et al. 2013). In addition to primary impact, mega landslide like recent case of Jure landslide in Nepal, and Tsatichhu landslide in Bhutan (Dunning et al. 2006) can result long term secondary and tertiary impact, and can undermine national economy. Knowing landslide prone areas and adopting appropriate development options (landuse planning alternative) is part of preparedness strategy to manage risk (Kamp et al. 2008).

ICIMOD under KBP, is preparing landslide susceptibility map using geo-spatial tool for Koshi Basin, and plans to develop multi-level landslide susceptibility mapping framework to be able to translate scientific and technical outputs to actionable information.

\subsection{Agricultural drought monitoring}

In Nepal, two third of total population depends on agriculture for their subsistence and more than one third of the Gross Domestic Product (GDP) comes from the Agriculture sector. Ensuring effective agriculture production across the country has been a serious challenge due to high degree of spatial and temporal climate variability, irrigated and rain fed agriculture 
systems coupled with farmer's fragile social and economic fabric and unique mountain practices. In this context, ICIMOD and the Ministry of Agricultural Development of Nepal have launched a collaborative initiative to develop an agriculture monitoring system (Figure 6) through conjunctive use of geospatial data, science and ground based information.

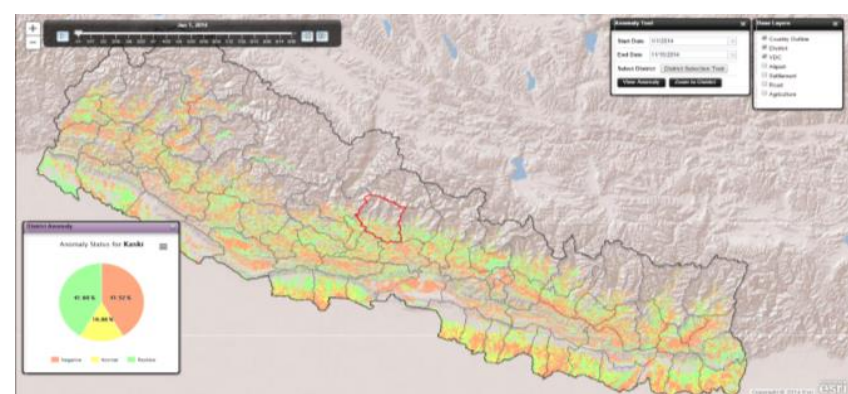

Figure 6. Interactive user interface of the agricultural drought monitoring system.

This application analyzes historical climate and crop condition patterns and compares this with the current growing season to provide timely assessment of crop growth. Using remote sensing data like Normalized Difference Vegetation Index (NDVI), Land Surface Temperature (LST) and Rainfall, the system-generated anomaly maps are inferred to predict the increase or shortfall in production. Comparisons can be made both spatially and in graphs and figures at District and Village Developmental Committee (VDC) levels. Timely information on possible anomalies in crop production is later used by institutions like the Nepal Ministry of Agricultural Development and World Food Programme - Nepal to trigger appropriate management response. Future potential includes integrating data on agricultural inputs, socioeconomics, demographics, and transportation to holistically assess food security in the region served by SERVIR-Himalaya.

\section{ENABLING EFFECTIVE RESPONSE THROUGH} ALERT AND RESPONSE MECHANISM

\subsection{Forest fire alert system}

Forest fire has already become national concern due to its impact on forest ecosystems and associated processes. The long and dry winter spell attributed to climate change is correlated to increase in the forest fire events in recent past. The need for effective forest fire management based both on technological input and community engagement is the best design ahead. ICIMOD under SERVIR Himalaya Initiative developed an alert system based on Moderate Resolution Image Spectroradiometer (MODIS) active forest fire in last 2 years. The system maps the active forest fire picked up by MODIS onto a GIS layers of administrative units, landcover, and digital elevation model (DEM). Based on the location of the fire point, SMS alert and e-mail alert are sent out to registered user from particular area which includes district forest officials and volunteers. The system uses fire points mapped using MODIS image from ground receiving station established at ICIMOD premises, thereby sending out alerts within 15 to $30 \mathrm{~min}$ after the satellite over pass.

\subsection{Emergency Management and Response System}

Based on the estimated amounts of potential slip accumulated by constant plate motions, it is said that large earthquakes in Himalaya are overdue (Bilham et al. 2001). Rapid and unplanned urban expansion has compromised on many aspects of disaster friendly development, rendering cities vulnerable to earthquake. In an event of a disaster event such as mega earthquake, urban centers particularly cities like Kathmandu will spell mega humanitarian crisis. Rescue and response would be impeded by access (access to information on amenities and critical infrastructure) constraints. In preparation, ICIMOD built a prototype Emergency Management and Response System (EMRS) to strengthen crisis response by access to information through one window system. The system developed for Kathmandu City is built on ArcGIS Server, and provides tools to find shortest route from point A to B; find alternative route in case of traffic disruption; and locate amenity centers like hospitals, petrol pump and fire brigades, etc. Importance of social media and crowd sourced information during disaster as in the case of Haiti Earthquake of 2010 is finding greater role in disaster management. The EMRS has integrated USAHIDI, an open source system to build in crowd provided information into the system, and SAHANA, an open source system to aid in logistic management.

The system was successfully tested to some extent during the Sikkim earthquake of 18 September 2011.

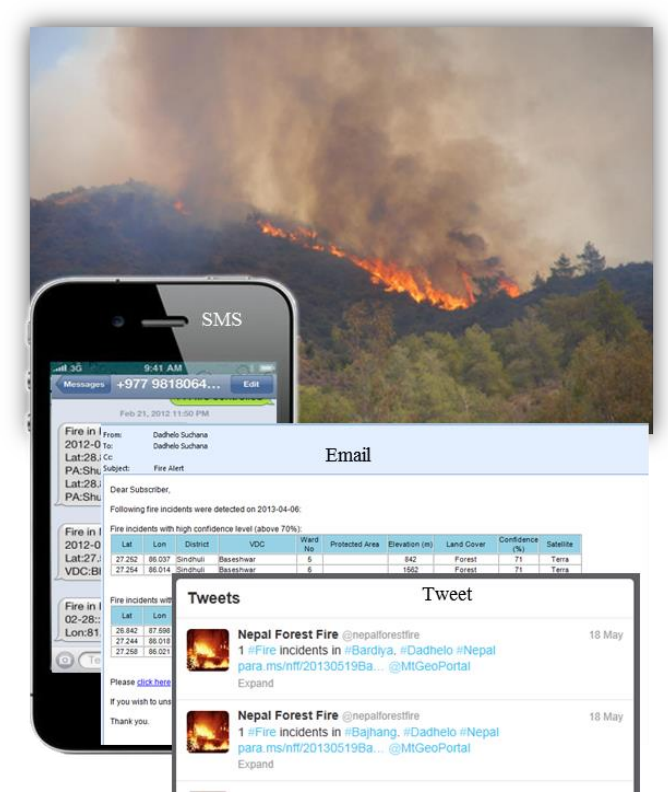

Figure 7. Forest fire alerts are sent out using different communication means.

\subsection{Radar Altimetry Satellite System for Operational Flood Forecasting}

Trans-boundary flood management is often hindered by accessibility challenges of river discharge information due to data sensitivity in geo-political setting. ICIMOD in collaboration with universities in United States and Institute of Water Modelling (IWM) in Bangladesh, has implemented flood forecasting in Bangladesh using radar altimetry (Hossain et al. 2014). The system uses JASON-2, a satellite designed to study sea surface height using a radar altimeter. It is put to use to detect river height in the upstream of Bangladesh where JASON-2 track intersects with river network (known as virtual station). Based on the established rating curve between river height (at virtual station) and discharge, discharge at upstream boundary points inside Bangladesh is estimated. Using this relationship, "Forecasting Rating Curves (FRC)" scheme is developed and 5 days discharge forecast at upstream boundary points inside Bangladesh (at Bahadurabad and Hardinge Bridge in Figure 8) is achieved using altimeter reading only. Using 
HEC-RAS model developed at the Hydrologic Engineering Center (HEC), forecasted water level at Bahadurabad and Hardinge Bridge is propagated to generate forecast of water level at the 17 flood warning locations (Figure 8).

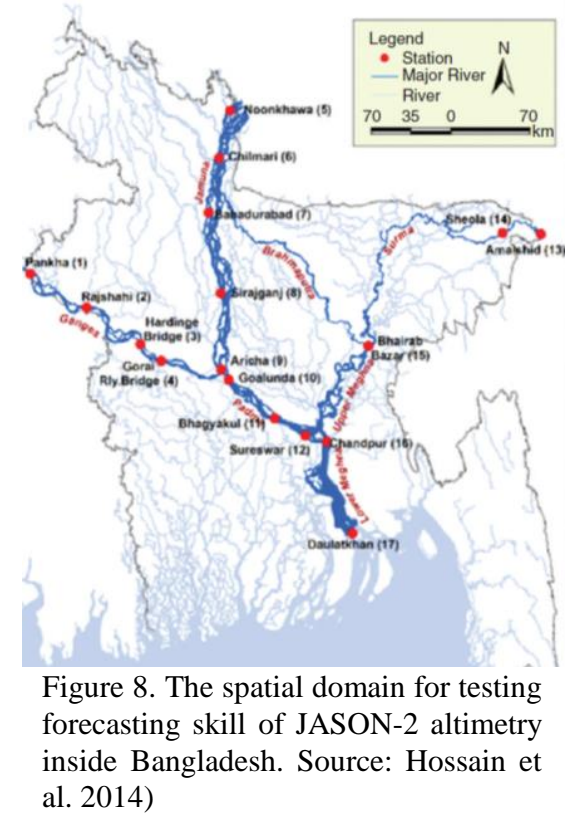

\subsection{Rapid response mapping}

Access to current and updated field information while disaster unfolds is crucial for effective response. Rapid response mapping in that regard has become integral part of post disaster response and there are regional and global mechanisms to facilitate the process providing free access to satellite data in an event of disaster. In response to the need for rapid response mapping support during Kosi flood of 2008 in Nepal, ICIMOD for the first time provided rapid response mapping support. Over the years ICIMOD has successfully inducted itself into rapid response mapping community with networks of national and international partners. ICIMOD is an active member of Sentinel Asia, a regional arrangement similar to International Charter for Space and Major Disaster under the leadership of Japan Aerospace Exploration Agency (JAXA) and Asian Disaster Reduction Center (ADRC). ICIMOD is regional data analysis node (DAN) of Sentinel Asia and is equipped with Wideband InterNetworking engineering test and Demonstration Satellite (WINDS) to access satellite data during disaster event. ICIMOD is also Regional Support Office (RSO) of UNSPIDER and is able invoke wider network through this arrangement. So far ICIMOD has responded to several events including Pakistan flood of 2010, Seti river flash flood of 2012 (Figure 9), and Jure landslide of 2014, and successfully supported response mechanism.

\section{DISCUSSION AND CONCLUSION}

The disaster managers, planners and policy makers across HKH countries faces challenges from myriad types of disaster, needing multi hazard approach and of multi-level engagement. While there is benefit in working across national boundary in collaborative framework to address shared problem due to trans-boundary nature of most disaster type. Devising solution for localized problems needs localized solutions. Devising solutions are challenged by accessibility issues due to physical terrain, and needs exploring innovative solutions like satellite based monitoring mechanism and wireless communication medium. Piloting customized package and providing affordable and simple solutions are important consideration to ensure up scaling opportunity, and sustainability of the interventions. Equally important is community engagement and ownership to ensure local solutions to succeed.

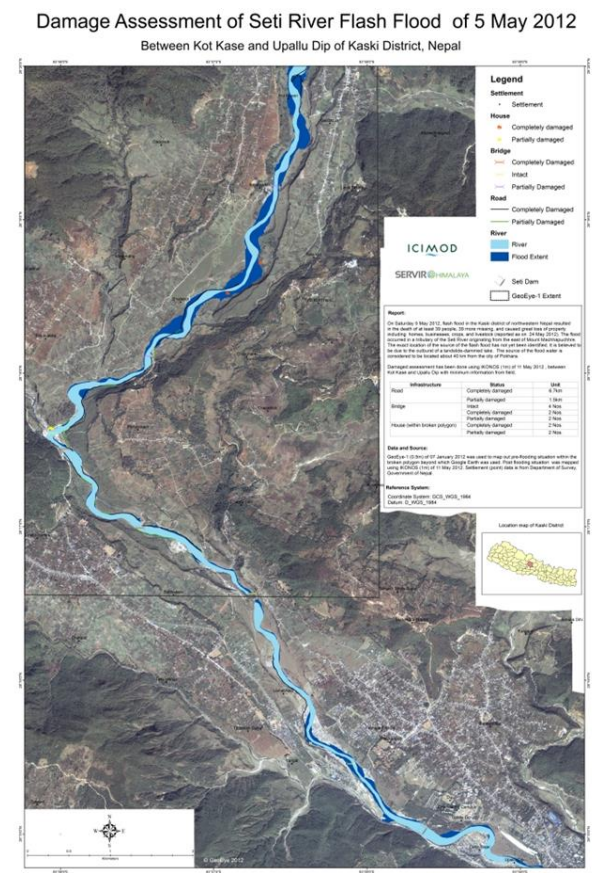

Figure 9. Rapid response mapping product of Seti river flash flood of Nepal in 2012.

\section{ACKNOWLEDGEMENT}

We are appreciative of the funding from whole host of donors who supported activities presented in this paper. The major ones being NASA, USAID, Norwegian Government, and Swedish Government. Contribution and collaboration from national governments and national partners are highly appreciated, without which idea would have just remained as concept. Thanks also goes to ICIMOD colleagues from different programs who contributed in implementing activities highlighted in this paper. The support received by ICIMOD from network of partners like JAXA, ADRC, UN-SPIDER is very much appreciated.

The views and interpretations in this publication are those of the authors. They are not necessarily attributable to ICIMOD and do not imply the expression of any opinion by ICIMOD concerning the legal status of any country, territory, city or area of its authority, or concerning the delimitation of its frontiers or boundaries, or the endorsement of any product

\section{REFERENCES}

Abdalla, R; Li, J (2010) 'Towards effective application of geospatial technologies for disaster management.' International Journal of Applied Earth Observation and Geoinformation 12(6): 405-407

ADAPT-Nepal. (2011). Preparedness for Flood Risk Reduction through Mapping and Assessing Risk and Management Options and Building Capacity in Lal Bakaiya Watershed, Nepal: ADAPT-Nepal.

Ali Tahir, M. (2007, 14-16 June 2007). The Needs and Geospatial Technologies Available for Disaster Management in Urban Environment. Paper presented at the Recent Advances in Space Technologies, 2007. RAST '07. 3rd International Conference on. 
Bajracharya, SR; Mool, KP; Shrestha, BR (Eds.). (2007). Impat of Climate Change on Himalayan Glaciers and Glacial Lakes: International Centre for Integrated Mountain Development.

Bajracharya, SR; Mool, P (2009) 'Glaciers, glacial lakes and glacial lake outburst floods in the Mount Everest region, Nepal.' Annals of glaciology. (53): 81-86

Bajracharya, SR; Shrestha, B. (2011). The Status of Glaciers in the Hindu Kush-Himalayan Region (pp. 127): ICIMOD.

Bajracharya, SR; Maharjan, SB; Shrestha, F (2014) 'The status and decadal change of glaciers in Bhutan from the 1980s to 2010 based on satellite data.' Annals of Glaciology 55(66): 159-166

Beniston, M (2003) 'Climatic Change in Mountain Regions: A Review of Possible Impacts.' [10.1023/A:1024458411589]. Climatic Change 59(1): 5-31

Bhattarai, B; Pradhan, A (2013) 'A Case Study on Landslide Hazard Mapping in Changunarayan VDC, Nepal.' In Margottini, C; Canuti, P; Sassa, K (eds) A Case Study on Landslide Hazard Mapping in Changunarayan VDC, Nepal, pp 551-559. Springer Berlin Heidelberg

Bilham, R; Gaur, VK; Molnar, P (2001) 'Himalayan seismic hazard.' Science 293: 3

Birkmann, J (2007) 'Risk and vulnerability indicators at different scales:Applicability, usefulness and policy implications.' Environmental Hazards 7(1): 20-31

Bolch, T; Buchroithner, MF; Peters, J; Baessler, M; Bajracharya, S (2008) 'Identification of glacier motion and potentially dangerous glacial lakes in the Mt. Everest region/Nepal using spaceborne imagery.' Nat. Hazards Earth Syst. Sci. Natural Hazards and Earth System Science 8(6): 1329-1340

Chen, K; McAneney, J; Blong, R; Leigh, R; Hunter, L; Magill, C (2004) 'Defining area at risk and its effect in catastrophe loss estimation: a dasymetric mapping approach.' Applied geography. 24(2): 97-117

Coumou, D; Rahmstorf, S (2012) 'A decade of weather extremes.' [10.1038/nclimate1452]. Nature Clim. Change advance online publication:

Das, PJ. (2011). Building community's capacity for flash flood risk management in the Jiadhal river basin in Dhemaji District, Assam, India: Aaranyak.

Dunning, S; Rosser, N; Petley, D; Massey, C (2006) 'Formation and failure of the Tsatichhu landslide dam, Bhutan.' Landslides 3(2): 107-113

Goodchild, MF (2006) 'GIS and disasters: Planning for catastrophe.' Computers, Environment and Urban Systems 30(3): 227-229

Hossain, F; Maswood, M; Siddique, EAAH; Yigzaw, W; Mazumdar, LC; Ahmed, T; Hossain, M; Shah-Newaz, SM; Limaye, A; Lee, H; Pradhan, S; Shrestha, B; Bajracahrya, B; Biancamaria, S; Shum, CK; Turk, FJ (2014) 'A promising radar altimetry satellite system for operational flood forecasting in flood-prone bangladesh.' IEEE Geosci. Remote Sens. Mag. IEEE Geoscience and Remote Sensing Magazine 2(3): 27-36

ICIMOD (2011) Glacial Lakes and Glacial Lake Outburst Floods in Nepal: ICIMOD

Ives, JD; Shrestha, RB; Mool, PK (2010) Formation of Glacial Lakes in the Hindu Kush-Himalayas and GLOF Risk Assessment. Kathamandu, Nepal: ICIMOD

ISDR. (2005). Hyogo Framework for Action 2005-2015 (pp. 22).

Kaab, A; Chiarle, M; Raup, B; Schneider, C (2007) 'Climate change impacts on mountain glaciers and permafrost.' Global and planetary change. 56(1): vii
Kamp, U; Growley, BJ; Khattak, GA; Owen, LA (2008) 'GISbased landslide susceptibility mapping for the 2005 Kashmir earthquake region.' Geomorphology 101(4): 631-642

Karma; Ageta, Y; Naito, N; Iwata, S; Yabuki, H (2003) 'Glacier distribution in the Himalayas and glacier shrinkage from 1963 to 1993 in the Bhutan Himalayas.' BULLETIN OF GLACIOLOGICAL RESEARCH 20: 29-40

Kayastha, P; Bijukchhen, S; Dhital, M; De Smedt, F (2013) 'GIS based landslide susceptibility mapping using a fuzzy logic approach: A case study from Ghurmi-Dhad Khola area, Eastern Nepal.' Journal of the Geological Society of India 82(3): 249261

Komori, J (2008) 'Recent expansions of glacial lakes in the Bhutan Himalayas.' Quaternary International 184(1): 177-186 Komori, J; Koike, T; Yamanokuchi, T; Tshering, P (2012) 'Glacial Lake Outburst Events in the Bhutan Himalayas.' Global Environmental Research 16: 12

Kuenza, K; Dorji, Y; Wangda, D. (2004). Landslide in Bhutan. Country Report (Mines, DoGa, Trans.) (pp. 8): Department of Geology and Mines.

Mennis, J (2003) 'Generating Surface Models of Population Using Dasymetric Mapping.' The Professional Geographer 55(1): 12

Mool, PK; Bajracharya, SR; Joshi, SP (Eds.). (2001a). Inventory of Glaciers, Glacial Lakes and Glacial Lake Outburst Floods. Monitoring and Early Warning Systems in the Hindu Kush-Himalayan Region, Nepal.: International Centre for Integrated Mountain Development.

Mool, PK; Wangda, D; Bajracharya, SR; K., K; Gurung, DR; Joshi, SP (2001b) Inventory of Glaciers, Glacial Lakes and Glacial Lake Outburst Floods: Monitoring and Early Warning Systems in the Hindu Kush Himalayan Region - Bhutan: International Centre for Integrated Mountain Development

Pareta, K; Kumar, J; Pareta, U (2012) 'Landslide Hazard Zonation using Quantitativer Methods in GIS '. International Journal of Geospatial Engineering and Technology 1(1): 9

Quincey, DJ; Richardson, SD; Luckman, A; Lucas, RM; Reynolds, JM; Hambrey, MJ; Glasser, NF (2007) 'Early recognition of glacial lake hazards in the Himalaya using remote sensing datasets.' Global and planetary change. 56(1): 137

Richardson, SD; Reynolds, JM (2000) 'An overview of glacial hazards in the Himalayas.' Quaternary International 65-66: 3147

Schiermeier, Q (2012) 'Disaster toll tallied.' Nature 481: 2

Shrestha, AB; Eriksson, M; Mool, P; Ghimire, P; Mishra, B; Khanal, NR (2010) 'Glacial lake outburst flood risk assessment of Sun Koshi basin, Nepal.' Geomatics, Natural Hazards and Risk 1(2): 157 - 169

UN. (2012). The future we want. Paper presented at the Rio+20, Rio de Janerio, Brazil.

Zerger, A; Smith, DI (2003) 'Impediments to using GIS for real-time disaster decision support.' Computers, Environment and Urban Systems 27(2): 123-141 